\title{
Teachers' Attitude Toward a Foreign Language: Factors Affecting the Target Language Teaching Process
}

\author{
Salwa Al Darwish ${ }^{1, *}$ \\ ${ }^{1}$ Public Authority for Applied Education \& Training, College of Basic Education, Kuwait, Kuwait \\ *Correspondence: Public Authority for Applied Education \& Training, College of Basic Education, Kuwait, Kuwait. \\ Tel: 965-9901-3946. E-mail: salwaaldarwish@hotmail.com
}

Received: July 8, 2017

Accepted: August 11, 2017 Online Published: November 16, 2017

doi:10.5430/ijelt.v5n1p1

URL: https://doi.org/10.5430/ijelt.v5n1p1

\begin{abstract}
The purpose of this study is to find out the teachers' attitude toward reaching effective teaching process as well as the key factors which influenced their attitude for selecting this profession. It

was carried out during the fall semester 2016/2017. The participants were 42 males and 117 female English language teachers, a total of 159 English teachers. They were all randomly selected and were all teaching English as a foreign language in different stages in Kuwaiti public elementary schools. The data was collected through a questionnaire and an individual interviews. The results mainly showed the teachers' attitude reflected on their passion to learn more about this language and its culture. Moreover, some teachers associate English language teaching with the language of the British Colonialization. Others see English simply as a means of doing business and making money.
\end{abstract}

Keywords: teachers' attitude, English language teaching, English as a foreign language, effective language teaching,

\section{Introduction}

Teaching is not merely an intellectual matter, it is to be considered an art or as the saying goes, "great teachers are born and not made" (Brosh, 1996). It draws on those experiences and resources that are uniquely defined and exhibited by the teacher's personality, which cannot be easily transferred to, or learned from, others. English language as a subject has spread around the world and most of the non-English speaking countries are interested in learning it for its value. Furthermore, people who are interested in learning English have different motivation and attitude toward that language. Although this is true, but to teach this language, teachers have to project some kind of an attitude and feeling toward it to the students (learners). In this sense the teachers' personality can be of the greatest importance in determining the learners' success or failure (Karavas, 1996).

Consequently, in a foreign language context, the learning process is affected by various factors such as motivation, attitudes, anxiety, learning achievements, aptitudes, intelligence, age, and personalities, (Yashima \& Zenuk, 2004). Among these affective factors, attitude which is a speculative idea that represents an individual's behavior in a positive or negative way toward someone or a language, is very decisive and essential contributor. Then, the instructors and educators should take this factor into account.

\subsection{Rational behind English Language Teachers' Attitude}

Teaching is a very personal activity, and it is not surprising that individual teachers bring to teaching very different beliefs and assumptions about what constitutes effective teaching. The majority of the English teachers have admitted the importance of language learning for employability, skills development, travel, enjoyment, cultural understanding, and communication.

Nevertheless, in the process of English language teaching, English language teachers are supposed to come to the classroom based on their perceptions of their students, school administration, curriculum and the society. Accordingly, these perceptions are responsible for their attitudes. Because teachers' attitudes have a great impact whether it's positive or negative on the teaching process, then, it is important to know what teachers adopt when it 
comes to teaching English as a foreign language. Moreover, foreign language teachers embrace different attitudes toward that language, English, which their attitudes may influence language learners by pushing them to behave in certain manners towards the language itself. Therefore, both positive and negative English language teachers' attitudes determine the success or the failure of this language teaching and learning. For this reason we need to find answers for the following research questions:

\section{Research Questions}

1. What determines the teachers' attitude to reach effective teaching process?

2. What are the key factors which influence the English language teachers' attitude for selecting this profession?

\section{Literature Review}

Munir defined that an attitude is a emotional and neutral state of readiness, organized through experience, applying a directive or active impact upon the individual response to all matters and situations with which it is related (2010). Garrett also adds that attitudes are more highly related to achievement than others especially when the perceptions of attitudes towards learning a second language are itself complex (2009). So, for teaching a foreign language, it can be facilitated if the teacher adopts positive and constructive attitudes towards that language, i.e. if the attitude is positive, learners language acquisition will be high; but if the attitude is negative, language learners acquisition will be low (Shams, 2008).

\subsection{Determiners of Teachers' Attitudes}

As English teachers, we measure our teaching successes and failures in contrast to norms shaped by others within our own profession $(\mathrm{Wu}, 2010)$. Yet we all know that our profession does not offer an imposing voice on attitudes toward this language, English. It doesn't associate for any professional organization or faculty staff to decide what we as English teachers should do or believe about teaching the English language. Instead, we are left to muck about in the half-light of our own wisdom, searching for our own answers and methods (Ely, 1986). Attitudes toward language will be as adaptive as the members of our profession choose to make it. Consequently, the factors which determine the teachers' attitudes are many. These factors depend on the individual role as well as the role of the environment.

\subsection{The Cultural Factor of the Target Language}

Attitudes toward English and English-speaking cultures will always contribute some tension to the teaching and learning of English, and the successful teacher will be aware of this factor, and try to use it in teaching (Alptekin et al., 1984). Alptekin and his colleagues added that teachers who have favorable attitudes towards a language, its speakers and their culture, tend to be more successful in their teaching than those who have negative attitudes (1984). Green and Shimizu explored the attitudes of 250 second language teachers toward Kanji and their choices of instructional strategies for teaching ( Kinjira, 2008). Their analysis shows that teacher attitudes toward teaching and learning are critical in determining the types of strategies used for teaching foreign languages and second languages (Al Darwish, 2006). Teacher attitudes were shown to be particularly important in students' success in learning foreign writing systems that differ significantly from that of the students' native language (William, 1975). Green and Shimizu note that as numerous approaches to teaching language have developed, it has become increasingly important to understand how beliefs and attitudes of individual language teachers toward the target language shape instructional strategies (2002). This fact is important because the particular style of language instruction used by a teacher may significantly impact the choices that students make in their efforts to develop effective learning strategies. Moreover, Kara says that a successful teacher is the one who possesses positive attitudes towards the target language and its culture (2009).

\subsection{The Social Factor of the Target Language}

Society can highly influence the teachers' attitudes towards teaching a specific language, i.e. society can create or destroy the teachers' desire to teach. Any general attitude could be positive or negative, so teachers before coming to class, they bring with them that attitude towards that language which is positive or negative. The acculturation model of Schumann holds that the most important influence on the success of second language learning as it is the main objective for the language teacher is the relationship between the social group of second language learners and the social group of the speakers of the target language (1978).

According to Schumann, when anxiety or stress or self-consciousness is high, as when there is tension between the 
two social groups, inductive acquisition is not likely to take place efficiently and incorrectly acquired forms are apt to become fixed. Yet the target language that is inductively acquired through interaction with members of a social group is extremely useful, as it is easily available to the language user for the construction of connected discourse in meaningful communication.

As the socio-educational model and the acculturation model make clear, teachers' attitudes toward the speakers of a target language, whether we identify with them and want to be like them, influence the ease with which we acquire and teacher the target language. As for Macnamara noted that a learner when suddenly was transported from one social context to the target language social context will swiftly learn the target language no matter what the learner thinks of the members of the social target language (1975). But as the learner reaches school age, he/ she will begin to acquire certain attitudes toward the target language that might interfere with further learning of the mother tongue language. (1975:79)

Likewise, John Oller and his colleagues conducted several large-scale studies of the relationship between attitudes and language success (Oller, Hudson, and Liu, 1977; Chihara and Oller, 1978; Oller, Baca, and Vigil, 1978). Oller and his colleagues revealed from their studies that when looking at the relationships between students' achievement in the target language to their attitudes toward self, their native language group, the target language group, and their reasons for learning and teaching the target language, they all yielded slightly differing conclusions from their studies. Nonetheless for the most part, teachers' positive attitudes toward self, toward the native language group, and toward the target language group enhanced proficiency. It seems clear that the second language learner benefits from teachers' positive attitudes and that teachers' negative attitudes may lead to decreased motivation, and probably poorer achievement.

\subsection{The Financial Factor for the Target Language}

Boyd et al. states that in some areas raising salaries attracts teachers particularly if these teachers are majoring in a subject such as English language and the country is in need for them (2003). Moreover, Santiago claims that salaries and alternative employment opportunities are decisive for teachers' attitudes toward carrying on with their profession (2004). He added that the higher the teachers' salaries the fewer these teachers will leave (Santiago, 2004). Also, Wolter \& Denzler conducted an analysis on teachers and came up with a conclusion that salary level is responsive to the teacher supply (2003).

\subsection{Personality Factor}

As Odden \& Carolyn state that a person's attitude toward certain target language symbolizes what an individual would like to achieve in the future whether by satisfying parents, receiving a reward as a career advancement or increasing salary, or being in the state of guilt and shame (1997). Consequently, individuals' images of their future will involve influential qualities such as employment and lifestyle, and integrative qualities such as wishing to be a cultured, well educated, and globally aware person(Clement, 1986). Although this is true, some teachers' attitude toward the target language involve their satisfaction of being English language teachers because the actual profession of teaching provides them with opportunity to work with students (Skaalvik et al., 2015). Additionally, The weight for applying the target language is not only the society's demand for improving the usage of the target language in different areas, but also to prepare the country's students to pursue their higher education abroad in one of the countries where the target language is their official first language (Yashima et al., 2004). Moreover, Tavil added that teachers' attitudes are supported by positive social relations with students' parents, colleagues and school leadership (2009). Likewise, Kokkinos emphasized that teachers' attitude toward their profession is a result of their stress caused by time pressure, discipline problems, and the lack of professional recognition (2007).

\subsection{Gender Difference Factor}

Theories and research studies show differences between male and female attitudes toward English language teaching. Appleby states that patterns of gender are clearly an affective part of the educational construction, as gender has always been associated with language teaching and learning (2014). She adds that the importance of gender lies in the knowledge that gender is connected directly with different opportunities and barriers which shape the composition of the language teachers. According to Dee, the teacher's gender not only shapes communication between teachers and students, but is also an important factor in portraying the teacher as a 'gender-specific role model' (2006). Bernat \& Lloyd looked at the aspect of teacher gender not in terms of being matched with their learners, but rather as a factor that impacts teaching skills and in turn influences learner performance (2007).

Besides, Manjari found out female teachers' attitude is higher than males' attitude (2005). In contrast, Kobayashi's study came to a conclusion that there are no differences in genders' attitude (2010). Hence, the teachers' gender and 
its influences emerge as an issue that not only affects teaching methods and the learning process, but also affects teachers and students' attitudes and learning assumptions. Consequently, Kobayashi's investigation came up with gender differences in attitude toward English language teaching (2010). He added that positive attitude for females is affected by the social elements in achieving better lives and their freedom from their society. Nevertheless, females' positive attitude as an educational element through using English as a dominant choice in schools and pursing their higher degrees in the countries where the target language is used (Kobayashi, 2010). Swain and Miccoli added that females emotions changes from anxiety and depression to confidence in teaching and learning a target language once they are exposed to collaborative teaching and learning in a target language classroom (1994).

\section{Methodology}

This research paper was carried out during the fall semester 2016/2017. The participants were 42 males and 117 female English language teachers, a total of 159 English teachers. They were all randomly selected and were all teaching English as a foreign language in different stages in Kuwaiti public elementary schools.

In order to achieve triangulation for this study, data was collected from two sources by using a questionnaire and an individual interviews over a period of three months. The questionnaire was distributed in different schools within the only six school district in Kuwait. Moreover, the questionnaire was organized based on strongly disagree to strongly agree. The aim of the first five statements (a-e) in the questionnaire is to investigate the participants' backgrounds. However, the interview was only carried out with six randomly selected teachers, one per school, from each school district, and the interview was conducted in English. Furthermore, the interviews were conducted individually for 15 minutes each.

\section{Data Analysis \& Discussion}

\subsection{Questionnaire Analysis}

Based on the analysis of the questionnaire and as it is shown in table 1, the age varies between a minimum 22 year old and a max of 65 with the average age of the test subjects to be 35 years old. The total participants count is 159 , with a ratio of male to female of 1:3 with Female count at 117 and male count at 42 .

Table 1. Number and Age of Participants

\begin{tabular}{ccc}
\hline Years of Experience & Count & Percent \\
\hline$>$ 15 Years & 45 & $28 \%$ \\
11-15 Years & 31 & $19 \%$ \\
1-5 Years & 30 & $19 \%$ \\
6-10 Years & 42 & $26 \%$ \\
Just Started & 11 & $7 \%$ \\
Grand Total & 159 & $100 \%$ \\
\hline
\end{tabular}

Table 2. Participants' Enrollment

\begin{tabular}{lcc}
\hline Institutions & $\begin{array}{c}\text { Count of Degree of } \\
\text { the participants }\end{array}$ & Percent \\
\hline Kuwait University & 46 & $29 \%$ \\
Others & 79 & $50 \%$ \\
PAAET & 25 & $16 \%$ \\
Private Universities in Kuwait & 4 & $3 \%$ \\
USA Universities & 5 & $3 \%$ \\
Grand Total & 159 & \\
\hline
\end{tabular}


The data in table 2 shows that participants (\%50) are mainly from other universities which these universities do not exist in Kuwait. This is due to the fact that the Kuwaiti Ministry of Education introduced English as a compulsory subject in the elementary school curriculum in 1993, as well as at the intermediate and high school levels. The decision to teach English in elementary schools came the recruitment of English teachers from Arab and other countries, to fill the vacant English teaching positions in the elementary, middle and high schools until sufficient Kuwaiti teachers could graduate and be trained from Kuwait University and the Public Authority for Applied Education and Training (PAAET) at that time. These two institutions of higher education in Kuwait are: first Kuwait University, which was inaugurated in the academic year 1966/ 1967 (Kuwait, 2002); the second is the Public Authority for Applied Education and Training (PAAET), which was founded in 1982.

Additionally, the results show that the number of participants (\%3) from the private universities in Kuwait and the US universities (\%3) whom contributed their feedback toward this study was very low because for more than three decades private higher education was banned in Kuwait and the number of students to leave Kuwait to study abroad was also small. The state owned, Kuwait University, was the only option for students who wanted to earn college degree, and could pursue their higher education. However, as the number of Kuwaitis became close to a million

during the 1990s, Kuwait University and PAAET simply could not keep up with the demand. Accordingly, the Kuwaiti Ministry of Higher Education settled on a cost effective approach which it turned to the private sector. So, Kuwait Government lifted a ban on private higher education which took place less than a decade ago, and decided that the best way to ensure the development of academically rigorous universities was to require all new institutions to have foreign partners.

Other results showed that the majority of the English language teachers have a big passion for learning language and especially the English language. In figure 1, statements (1-6) demonstrate the majority of the participants have the desire to learn more about the English language as indicated a strong agreement to the statements. Statements 16-22 also indicate the participants' ambition to continue teaching the English language as they see it to be a significant language in a career path. Statements 13 and 15 showed a large disagreement to the statements. This is an indication of the participants understanding of the need to teach English language in the institutions they are in, and how they consider English language is a vital part of their life.

\subsection{Interview Analysis}

According to the researcher's interview, one question was asked "why the English language teachers chose to be an English teachers than any other subjects". Some participants expressed their freedom in possessing their own identity in speaking the English language as part of a community of lingua franca; as this would give them confidence as English speakers and English teachers, which in return it impacts positively on their attitude toward the language.

Other participants admitted that the primary reason for selecting English as a career because all teachers were once students, and their attitudes and beliefs about teaching are often a reflection of how they themselves were taught. They think that teaching the English language is not only limited to teach the ministry curriculum guide, but to try to give the learners some understanding in the language itself and its culture.

Moreover, some teachers believe English language teaching represent the language of the English speaking world. Some associate it with the language of the British Colonialization. Others see English simply as a means of doing business and making money.

On the other hand, some teachers thought that when they speak the language they lose their identity as an Arab individual, especially if they are asked as being native speakers. This had many possible social and personal limitations that may have influenced their choice for being English language teachers. For example:

- The teachers poor performance in English in the past as they were learners and how they became reluctant to speak for fear of making a fool of themselves;

- Being insecure and fearful which made them unable to say a word for fear of making a mistake in front of a teacher and laughing classmates. 


\section{Participents Answers to the statements}

22- Because I am an English language teacher, I should avoid word to word translation

21- Because I am an English language teacher, I should always practice English with others

20- I as a teacher should be a guide in teaching English

19- English is essential for my career

18- English is needed in getting a good job

17- I am motivated to teach the English language because I know it is paid well globally

16-I really enjoy teaching English

15- Knowing English isn't an important goal in my life

14- The aim of English language teaching is to understand spoken English on TV. And the radio

13- My English class is really a waste of time

12- The aim of English language teaching is to be encouraged to speak English abroad

11- I read in English for pleasure

10- The aim of English language teaching is to read English newspapers

9- The aim of English language teaching is to teach the culture of the target language

8- I am not afraid of speaking English publicly

7- English language enables me to better recognize and appreciate the English way of life

6-Knowing English will allow me to be more at ease with people who speak it

5- I look for opportunities to speak English with other people

4- The aim of English language Teaching is to help learners to communicate in English

3- English subject is an important part of the school program

2-Advantages for Learning English are really countless

1-I wish I can speak many foreign languages

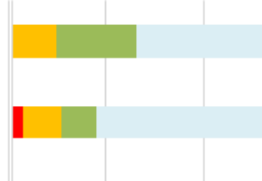




\section{Conclusion}

The degree to which individual teachers have a sense of professionalism about their work depends upon their own working conditions, their personal goals and attitudes, and the career prospects available to language teachers in their community. A great emphasis has been made in the field of attitudes and its effects on second/foreign language acquisition. This means that attitudes has deep impact on teachers in shaping their attitudes towards the target language. Teachers' attitudes can greatly influence their target language teaching and learners' achievement in the target language if these language teachers have a healthy self-respect and believe in themselves as English language teachers. The result of this study can help teachers adjust their attitude toward teaching the target language based on encouraging these teachers to become English language teachers and lower the barriers and make English language learning take place. Also, if these English teachers are well aware of what the learners' parents really think of foreign language and its speakers and how can those language teachers indirectly model and communicate the learners and their parents' attitudes toward this language and its community. This process may support the learners' academic progress in this language and as a result the learners would pick up the desirable and constructive message which will raise cross cultural awareness.

\section{References}

Al Darwish, Salwa. (2006). An Investigation of teachers' perceptions of the English language curriculum in Kuwaiti elementary schools. Unpublished doctoral dissertation, University of Denver, Colorado, USA.

Alptekin, C., \& Alptekin, M. (1984). The question of Culture: EFL teaching in non- English speaking countries. ELT Journal, 38(1), 14-20. http://dx.doi.org/10.1093/elt/38.1.14

Appleby, R. (2014). Men and Masculinities in Global English Language Teaching. Palgrave Macmillan: Houndmills, UK. http://dx.doi.org/10.1057/9781137331809

Bernat, E., \& Lloyd, R. (2007). Exploring the Gender Effect of EFL Learners' Beliefs about Language Learning. Australian Journal of Educational \& Developmental Psychology, 7, 79-91.

Boyd, D. H.; Lankford, S.; Loeb \& Wyckoff, J. (2003). Understanding Teacher Labor Markets: Implications for Educational Equity. 2003 Yearbook of the American Education Finance Association, Eye on Education, Larchmont, New York.

Brosh, H. (1996). Perceived characteristics of the effective language teachers. Foreign Language Annals, 29(2), 125-138. http://dx.doi.org/10.1111/j.1944-9720.1996.tb02322.x

Clement, R. (1986). Second language proficiency and acculturation: An investigation of the effects of language status and individual characteristics. Journal of Language and Social Psychology, 5(4), 271-290. http://dx.doi.org/10.1177/0261927X8600500403

Dee, T. (2006). The Why: How a Teacher's Gender Affects Boys and Girls. Educational Next/ Fall 2006.

Ely, C. M. (1986). An analysis of discomfort, risk-taking, sociability, and motivation in the L2 classroom. Language Learning, 36, 1-25. http://dx.doi.org/10.1111/j.1467-1770.1986.tb00366.x

Garrett, Peter. (2010). Attitudes to language. Cambridge: Cambridge University Press.

Green, K. and Shimizu, H. (2002). Japanese language educators' strategies for and attitudes toward teaching Kanji. The Modern Language Journal, 86(ii), 227-241.

Kanjira, Timothy Jameson. (2008). Motivation and Attitudes Towards English as a Second Language (ESL) Among Learners in Rural Kwazulu-Natal High Schools. Retrieved from http://uzspace.uzulu.ac.za/handle/10530/225

Kara, A. (2009). The Effect of 'learning theories' unit on students' attitudes towards learning. Australian Journal of Teacher Education, 34(3), 100-113.

Karavas- Doukas, E. (1996). Using attitude scales to investigate teachers' attitude to communicative approach. ELT Journal, 50(3), 187-198. http://doi.org/10.1093/elt/50.4377

Kobayashi, Yoko. (2010). The role of gender in foreign language learning attitudes: Japanese female students' attitudes towards English learning. Gender and Education, 14(2), 181-187. http://dx.doi.org/10.5539/ies.v8n3p181

Kokkinos, C. M. (2007). Job stressors, personality and burnout in primary school teachers. British Journal of Educational Psychology, 77, 229-243. http://dx.doi.org/101348/00709905X90344 
Kuwait Ministry of Planning, Statistic and Information Sector. (2002). Annual Statistical Abstract (39 ${ }^{\text {th }}$ ed.) Kuwait: Government Printing Office.

Macnamara, J. (1975). Comparison between first and second language learning. Working Papers on Bilingualism, 7 , pp. 71-94.

Manjari, S. (2005). Gender issues in the language arts classroom. Eric Digest. Bloomington, I.N. English Language Teaching, 8(12), 190.

Munir, Shuib. (2010). Language Learning Motivation: The Palestinian Context. Attitudes, Motivation, and Orientation". University of Barcelona.

Odden, Allan \& Carolyn, Kelley. (1997). Paying teachers for what they know and do. Thousand Oaks, CA: Corwin Press.

Oller, J., Baca, A., \& Vigil, A. (1978). Attitudes and attained proficiency in ESL: A sociolinguistic study of Mexican-American in the Southwest. TESOL Quarterly, 11, 173-183.

Oller, J., Hudson, A., \& Liu, P. (1977). Attitudes and attained proficiency in ESL: A sociolinguistic study of native speakers of Chinese in the United States. Language Learning, 27, 1-27

Santiago, P. (2004). The Labor Market for Teachers. In G. Johnes and J. Johmes (eds.), International Handbook on the Economics of education, Edward Elgar, Cheltenham, UK.

Shams, M. (2008). Students' attitudes, motivation and anxiety towards English language learning. Journal of Research, 2(2), 121-144.

Skaalvik, Einar \& Skaalvik, Sidsel. (2015). Job satisfaction, Stree and Coping Strategies in the Teaching ProfessionWhat Do Teachers Say? International Education Studies, 8(3), 181-192. http://dx.doi.org/10.5539/ies.v8n3p181

Swain, M., \& Miccoli, I. (1994). Learning in context-based collaboratively structured course: the experience of an adult ESL learner. TESL, 1, 15-28.

Tavil, Z. (2009). Parental Attitudes towards English Education for Kindergarten Students in Turkey. Kastamonu Education Journal, 17(1), 331-340.

Wolter, Stefan C., \& Denzler, Stefan. (2003). Wage Elasticity of the Teacher Supply in Switzerland. https://ssrn.com/abstract $=391984$

Wu, Kun-huel. (2010). The Relationship between Language learners' Aniety and learning Strategy in the CLT Classrooms. International Education Studies, 3(1), February 2010.

Yashima, Tomoko; Zenuk-Nishide, Lori \& Shumizu, Kazuaki. (2004). The influence of attitude and affect on willingness to communicate and second language communication. Language Learning, 54(1), 119-154. 